Ks. Ryszard GROŃ*

\title{
BIOGRAF AELREDA Z RIEVAULX I JEGO ŹRÓDŁA
}

Z całą odpowiedzialnością można powiedzieć, że życie i twórczość słynnego cysterskiego opata $\mathrm{z}$ dwunastowiecznego klasztoru angielskiego w Rievaulx, Aelreda, są dziś coraz powszechniej znane. Na sukces tej powszechniejszej znajomości złożyła się praca wielu specjalistów problematyki monastycznej, szczególnie z ostatnich dwóch stuleci. Pierwszy impuls po mrokach wielowiekowego zapomnienia o nim $^{1}$ dały badania zmarłego prof. Oxfordu Fredericka Maurice'a Powicke, który, jak sam wyznał, został zmotywowany do zajęcia się postacią Aelreda (choć z początku drugorzędnie) przez swego promotora Roberta Fawtiera ${ }^{2}$. Powicke po raz pierwszy przetłumaczył z łaciny na język angielski i krytycznie wyłożył Vita Aelredi, podstawowy utwór autorstwa Waltera Daniela, traktujący o życiu Aelreda ${ }^{3}$. Dotychczas znajomość tego dzieła, jak i samych utworów wielkiego cystersa z Anglii, była ograniczona tylko do ścisłego grona osób fachowo zajmujących się badaniami monastycyzmu epoki średniowiecza, pokroju wielkiego Dawida Knowlesa czy André Wilmarta. Dziś po latach, dzięki wkładowi tego i następnych pokoleń badaczy, którzy przetłumaczyli na języki nowożytne dzieła Aelreda i poddali je krytycznej weryfikacji, mamy pełniejszy wgląd w życie i twórczość opata z Rievaulx.

Same badania szły mozolnie ze względu na właściwy dla średniowiecza hagiograficzny charakter utworu o życiu Aelreda, którym się zajmowano. Jego dosłowne i bezkrytyczne traktowanie wprowadzało nieraz w błąd i może dalej wprowadzać wielu czytelników. Dopiero ustalenie pewnych prawideł, które dyktuje hagiograficzny charakter utworu, oraz uzupełnienie ich innymi źródłami historycznymi i literackimi, pozwala uniknać wielu możliwych nieporozumień. Artykuł ma za zadanie prześledzić, na czym polega biograficzny charakter utworu Waltera Daniela poświęconego życiu Aelreda oraz skąd autor

\footnotetext{
* Ks. dr Ryszard Groń - absolwent Wydziału Teologicznego Uniwersytetu Nawarry w Pampelunie (Hiszpania); e-mail: ryszardgron@wp.pl.

${ }^{1}$ Więcej na ten temat, zob. R. Groń, Aelred z Rievaulx - wielki zapomniany średniowiecza, WPT 13 (2005) z. 1, 19-37.

${ }^{2}$ Por. F.M. Powicke, Preface, w: Walter Daniel, The Life of Ailred of Rievaulx, ed. and transl. by F.M. Powicke, London - New York 1963 (reprint z roku 1950), s. VII.

${ }^{3}$ Po raz pierwszy tekst został zamieszczony w: F.M. Powicke, Ailred of Rievaulx and His Biographer Walter Daniel, „The Bulletin of the John Rylands Library” 6 (1922) nr 3-4, 71-112.
} 
czerpał swe wiadomości i jak je przedstawiał? To będzie tłumaczyć dlaczego jego opis życia opata z Rievaulx wymaga uwzględnienia innych obiektywnych i wiarygodnych źródeł dla odtworzenia prawdziwej biografii omawianej postaci. Podstawowych odpowiedzi na powyższe pytania należy szukać w źródłach biografii.

1. Podstawowe źródło biografii Aelreda z Rievaulx. Jak wspomnieliśmy, podstawowym źródłem biografii Aelreda jest łaciński utwór autorstwa Waltera Daniela zatytułowany Vita Aelredi (Żywot Aelreda). Badania Powicke wykazały, że dotychczasowa znajomość biografii opata z Rievaulx miała swe źródło właśnie w tym łacińskim utworze Waltera ${ }^{4}$. Zachował się on w jedynym rękopisie, który według Montague Rhodes Jamesa miał powstać w środowisku klasztornym Durham pod koniec XIV w., a dziś jest przechowywany w bibliotece

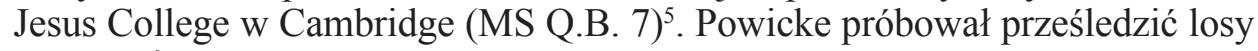
rękopisu ${ }^{6}$ sposób, w jaki stał się on źródłem dla dwóch innych średniowiecznych biografii Aelreda z końca XIV w. Pierwsza biografia napisana przez Johna Tynemoutha, mnicha z St. Albany, została zamieszczona w jego Sanctilogium Angliae (Żywoty Świętych Anglii), stając się z kolei źródłem wersji drukowanej, wydanej (1516) przez Johna Capgrave'a w Nova Legenda Angliae (Nowa legenda Anglii), pod datą 12 stycznia, a więc dnia śmierci Aelreda; stąd była ponownie przedrukowana przez Bolandystów w Acta Sanctorum (1643). Druga biografia Aelreda (w nieco dłuższej wersji), nieznanego z imienia autora, zachowała się w rękopisie pochodzącym z Bury St. Edmund (z 1377), przechowywanym dziś w Bodleian (MS Bodley 240$)^{7}$. Obydwa życiorysy przedrukował Carl Horstman w 1901 r. w Nova Legenda Angliae ${ }^{8}$.

Obydwie biografie, będące w istocie streszczeniem Vita Aelredi, mają dziś wartość historyczną, wskazując na podstawowe źródło, z którego wspomniani wyżej autorzy zaczerpnęli swe wiadomości. Jak widać, pionierska praca Powicke nad Vita Aelredi jest kluczowa dla wszelkich późniejszych badań nad Aelredem. Po raz pierwszy w 1865 r. utwór ten zauważył Sir Thomas Duffus Hardy ${ }^{9}$, lecz - jak zaznacza Powicke - uszedł on uwadze hagiografów. Nie znał go szesnastowieczny antykwariusz angielski John Leland; nie widniał też

\footnotetext{
${ }^{4}$ Por. Powicke, Introduction, s. xxviii-xxxii.

${ }^{5}$ Por. M.R. James, Descriptive Catalogue of the Manuscripts in the Library of Jesus College, Cambridge 1895, 28-29.

${ }^{6}$ Powicke (Introduction, s. XXIX, nota 2) twierdzi, że jeszcze w XV w. istniał inny rękopis Vita Aelredi obecny w bibliotece Citeaux, ale nie ma wiedzy, jak tam mógł się on znaleźć; potem jednak i ten zaginął; powołuje się na specjalny katalog skompilowany przez opata Johna de Cirey z roku 1480.

${ }^{7}$ Por. Powicke, Introduction, s. XXVIII-XXXII.

${ }^{8}$ C. Horstman, Nova Legenda Angliae, vol. 1, Oxford 1901, 41-46 (De sancto Alredo abbate et confessore); vol. 2, 544-553 (Anonymus, Incipit compendium vite sancti Aelredi abbatis Rievallie).

${ }^{9}$ Por. T.D. Hardy, Descriptive Catalogue of Materials relating to the History of Great Britain and Ireland, vol. 2, London 1865, 282.
} 
w średniowiecznym katalogu biblioteki w Rievaulx, aczkolwiek był on tam w XV w., na co wskazuje cytat zaczerpnięty z niego i dodany do innego utworu Aelreda pochodzącego właśnie stamtąd ${ }^{10}$. Przetrwał jedynie wspomniany wcześniej czternastowieczny manuskrypt z Durham. Został on nabyty przez Thomasa Mana pod koniec XVII w. i tak dostał się wraz z innymi rękopisami do Jesus College, Cambridge ${ }^{11}$. W interesującym nas manuskrypcie MS Q.B. 7 zajmuje on strony (foliały) od 63 do 74.

Występuje on tam jednak w kontekście dwóch innych mniejszych utworów tego samego autora, które znalazły się tu nieprzypadkowo. Poprzedza go mianowicie, tzw. List do Maurycego (Epistola ad Mauricium) ${ }^{12}$, który zajmuje strony: 61a-63b; a zaraz po właściwym utworze Vita następuje tzw. Lamentacja (Lamentacio), czyli żałobne wspomnienie po Aelredzie, które zajmuje strony: 74a-75b ${ }^{13}$. Z analizy tych utworów wynika, że Vita Aelredi powstał jako pierwszy, w celu pokazania świętego życia Aelreda, z uwypukleniem jego szczególnych cnót chrześcijańskich i cudów, co wywołało reakcje dwóch znanych osobistości zakonnych (nazwanych tu prałatami), którzy nie dali temu wiary. Niejaki Maurycy, którego dziś trudno zidentyfikowaći ${ }^{14}$, pokazał Vita Aelredi dwóm wspomnianym prałatom, którzy zarzucili jego autorowi kłamstwo i manipulację ${ }^{15}$. List do Maurycego ma być odpowiedzią Waltera na tę reakcję i próbą uściślenia jego stanowiska, tłumaczącego właściwe rozumienie świętości opata z Rievaulx. List ten jako pierwszy w rękopisie umieścił sam autor ${ }^{16}$. Lamentacja jest forma żałobnego wspomnienia Aelreda i zapewne powstała jako żałobny dodatek do Vita Aelredi; jako taka, wraz z Listem do Maurycego, stanowi dodatkowe źródło biografii opata ${ }^{17}$. Autorstwo wszystkich trzech utworów bez cienia wątpliwości powszechnie

\footnotetext{
${ }^{10}$ Por. Powicke, w: Walter Daniel, The Life of Ailred of Rievaulx, s. 58, nota 1.

${ }^{11}$ Por. tenże, Introduction, s. XXIX.

${ }^{12}$ Epistula ad Mauricium, ed. i thum. angielskie F.M. Powicke, w: Walter Daniel, The Life of Ailred of Rievaulx, s. 65-81.

${ }^{13}$ Powicke, Introduction, s. XXIX-XXXI.

${ }^{14}$ Powicke (Introduction, s. XXX-XXXI oraz nota 3) rozpatruje ewentualnie dwie osoby o tym imieniu: uczonego poprzednika Aelreda w Rievaulx, wybranego na opata po Wilhelmie w 1145 r., który dwa lata później zrezygnował ze swej funkcji i dalej żył w Rievaulx, oraz (bardziej się przychylając do osoby) przeora zgromadzenia kanoników regularnych z Kirkham (od 1167), który nie krył swej niechęci do Aelreda i krytykował jego zasługi; współczesna badaczka amerykańska z Ohio, Marsha Dutton, opowiada się bardziej za tą ostatnią kandydaturą, która miała swoje powody, by nie lubić Aelreda za sprawę odejścia od kanoników regularnych do cystersów Waldefa, przyjaciela Aelreda, za jego też pewnie namową; szerzej na ten temat zob. M. Dutton, Introduction to Walter Daniel's 'Vita Aelredi', w: Walter Daniel, The Life of Aelred of Rievaulx \& the Letter to Maurice, Kalamazoo 1994, 66-67.

${ }^{15}$ Por. Walter Daniel, Epistula ad Mauricium 66.

${ }^{16}$ Por. tamże 81.

${ }^{17}$ Szerzej na temat obydwu utworów zob. Dutton, Introduction, s. 66-74.
} 
przypisuje się Walterowi Danielowi ${ }^{18}$, we wszystkich bowiem widać jego wybuchowy i żywiołowy charakter ${ }^{19}$.

2. Walter Daniel - autor Vita Aelredi. Pierwsze zdania Vita Aelredi sugerują, że to niejaki ,opat H” jest pomysłodawcą spisania życiorysu Aelreda, a zadanie to zlecił właśnie Walterowi Danielowi, w krótkim czasie po śmierci Aelreda ${ }^{20}$. Badacze zgodnie twierdzą, że trudno zidentyfikować tożsamość tego opata, aczkolwiek idąc za wskazówką Powicke można widzieć w nim Hugona, opata filialnego w stosunku do opactwa Rievaulx klasztoru w Revesby, któremu miał przewodzić po 1166 roku $^{21}$. Krytyczna analiza tekstu w porównaniu ze wspomnianym już Listem do Maurycego wskazuje na to, iż należał on do stronnictwa sprzymierzeńców zmarłego opata z Rievaulx, próbując zachować po nim dobrą pamięć świetnego włodarza, a jednocześnie pokazać jego świątobliwe życie zakonne, wbrew pewnej nielicznej opozycji mnichów, jaka pojawiła się po jego śmierci, w ramach czy poza macierzystym klasztorem ${ }^{22}$. Marsha Dutton argumentuje, że wybór jaki padł na Waltera Daniela jako autora Vita Aelredi, był podyktowany wieloma czynnikami ${ }^{23}$. Przede wszystkim, Daniel był mnichem będącym pod okiem opata Aelreda przez 17 lat ${ }^{24}$, stając się z czasem jego bliskim przyjacielem. Miał on szczególny kontakt z nim w ostatnich (czterech) latach jego schorowanego życia ${ }^{25}$. Wtedy służył mu w charakterze pielęgniarza i na pewno osobistego sekretarza. Ponadto uchodził w klasztorze za wykształconego pisarza z pewnym dorobkiem teologicznym. Wydaje się, że nie można było znaleźć lepszego kandydata do napisania życiorysu zmarłego opata.

Podstawy takiego rozumienia roli Waltera, jako biografa Aelreda, dają badania profesora F.M. Powicke ${ }^{26}$. Biorąc pod uwagę słowa o siedemnastu la-

${ }^{18}$ Posługuję się tekstem Vita Aelredi w wydaniu F.M. Powicke wraz z jego komentarzami: Walter Daniel, The Life of Ailred of Rievaulx, London - New York 1963 (reprint z roku 1950), tekst łaciński i angielski, s. 1-64 (rozdz. 1-60, F. 63c - 74a); wszystkie polskie tłumaczenia tekstu są własne. O autorstwie Waltera Daniela Vita Aelredi, zob. Walter Daniel, Vita Aelredi 1.

${ }^{19}$ Por. Powicke, Introduction, s. XXIX.

${ }^{20}$ Walter Daniel, Vita Aelredi 1, ed. Powicke, s. F. 63c: „Virorum dulcissimo abbati H, suus W. Daniel, laborem et salute [...]. Non possum, fateor, tibi in hac re sensus mei racionem et scienciam denegare, cuius debeo pro uiribus parere preceptis et maxime in caritatiua iussione que non sine uecacione anime poterit preteriri, unde dicitur: «Pre uictima est obediencia et ante pinguium arietum oblacionem». Ad hanc nichilominus tuam intentacionem accedit et imminet recens patris abscessio que nos ultro prodire prouocat, obedire iubet, et tuis ammonet parere mandatis" [we wszystkich przytaczanych tekstach łacińskich zachowano oryginalną pisownię i ortografię].

${ }^{21}$ Por. tamże 1. Zob. Powicke, Introduction, s. XXIX I LXX.

${ }^{22}$ Por. Dutton, Introduction, s. 8-9.

${ }^{23}$ Por. tamże, s. 9-19.

${ }^{24}$ Por. Walter Daniel, Vita Aelredi 40.

${ }^{25}$ Por. tamże 49-64.

${ }^{26}$ Por. Powicke, Introduction, s. XI-XXVII. 
tach przeżytych pod rządami Aelreda oraz moment śmierci opata w $1167 \mathrm{r}$., twierdzi, że mógł on wstapić do klasztoru w Rievaulx ok. 1150 r., gdzie Aelred był już opatem od trzech lat. Jego ojciec, również Daniel, był w tym czasie mnichem w Rievaulx mając swój udział w sprawach administrowania posiadłości opactwa ${ }^{27}$. Dutton, idąc za wskazówką Vita Aelredi sugeruje, że decyzja Waltera wstąpienia do zakonu mogła być podyktowana wpływem samego Aelreda, w czasie, kiedy wizytował swego ojca Daniela w opactwie Rievaul ${ }^{28}$. Powicke dowodzi, że tytuł dominus, jakim go nazwał $\operatorname{syn}^{29}$, wskazuje na jego szlacheckie pochodzenie ${ }^{30}$. Natomiast sam Walter nosił tytuł magister, co miało wskazywać na jego wykształcenie filozoficzno-teologiczne, jakie zdobył przed wyborem życia zakonnego w Yorku lub Durham ${ }^{31}$. Świadectwem tego może być bogata spuścizna literacka, o której wspominają antykwariusze John Leland i John Bale (XVI w.), twierdząc, że widzieli w bibliotece klasztoru Rievaulx, przed jego protestancką kasacją, dziewięć rękopisów Waltera Daniela, których rejestr podali ${ }^{32}$. Niestety brakowało tam Vita Aelredi. Jednak zachowały się jego Centum Sententiae (Sto sentencji) i kazania, które pokazują poziom jego wykształcenia w duchu monastycznym, choć, jak twierdzi Powicke, był on uboższy i mniej oryginalny od Aelreda ${ }^{33}$.

Powicke twierdzi, że skoro Walter był magistrem w wieku 25 lat, a więc wówczas, kiedy odwiedzał swego ojca w Rievaulx, to w chwili śmierci Aelreda, kiedy spisywał jego Vita, mógł mieć 42 lata. W tym czasie mógł też sprawować w klasztorze ważną funkcję infirmarza, odpowiedzialnego również za przygotowywanie ciał zmarłych mnichów do pochówku (obedientiaries), co pasowałoby do określenia jego posługiwania w załączonej do Vita lamentacji jako officio medicus (urząd medyka) ${ }^{34}$. Vita pokazuje go w wykonywaniu tych czynności ${ }^{35}$, które - jak zauważa profesor z Oxfordu - musiały należeć do ważnych funkcji w klasztorze. $Z$ wyżej wymienionych racji oraz zdolności intelektualnych, Walter musiał mieć znaczny autorytet i wpływ w swej wspólnocie w Rievaul ${ }^{36}$. Na tym tle nie dziwi, że stał się w sposób naturalny akceptowanym biografem i obrońcą Aelreda, mającym przyzwolenie wspólnoty

${ }^{27}$ Por. Walter Daniel, Vita Aelredi 35 i 68.

${ }^{28}$ Por. tamże 2; Dutton, Introduction, s. 10.

${ }^{29}$ Por. Walter Daniel, Epistula ad Mauricium 68.

${ }^{30}$ Por. Powicke, Introduction, s. XII-XIV. Mógł pochodzić z rodu Balliol fief w Cleveland, zob. tamże, s. XLII.

${ }^{31}$ Por. tamże, s. XIV-XV.

${ }^{32}$ Por. tamże, s. XVI-XVII.

${ }^{33}$ Por. tamże, s. XIX-XXVI.

${ }^{34}$ Por. tamże, s. XXVI, nota 1; tekst Lamentacji w przekładzie P. Freelanda na język angielski został zamieszczony w: Walter Daniel, The Life of Aelred of Rievaulx \& the Letter to Maurice, s. $140-146$.

${ }^{35}$ Por. Walter Daniel, Vita Aelredi 62-64.

${ }^{36}$ Por. Powicke, Introduction, s. XXVI. 
oraz zaplecze intelektualne. Badacze, za profesorem z Oxfordu, wiążą postać Waltera z jednym z bohaterów dialogów Aelreda o przyjaźni, zwanym również Walterem, uwypuklając jego walory intelektualne oraz negatywne cechy charakteru, takie jak: impulsywność, egocentryzm, arogancja czy zazdrośćc ${ }^{37}$. Powicke zauważa, że Walter był później szanowany w Rievaulx. Mógł żyć tam jeszcze wiele lat po śmierci Aelreda, stając się duchowym liderem życia monastycznego północnej Angliii ${ }^{38}$. Nic nie wiadomo o jego śmierci, która mogła nastąpić w klasztorze w Rievaulx.

Więcej na temat autora Vita Aelredi dowiadujemy się z lektury jego utworu oraz z niektórych pism Aelreda. Pod tym względem można śmiało polegać na analizach dokonanych przez M. Dutton ${ }^{39}$. Oprócz wiadomości podanych wcześniej przez Powicke, można mieć pewność, że Walter wykazuje się znajomością wielu szczegółów z życia swego opata, szczególnie z ostatniej dekady, co wskazuje na to, iż miał z nim bardzo częsty kontakt. Sam wyznaje, że był sekretarzem spisującym jego dzieła ${ }^{40}$. Nie ulega też wątpliwości, że był pielęgniarzem klasztornym, a przynajmniej Aelreda, ponieważ niemalże non stop przebywał przy łóżku chorego opata, podczas gdy inni mnisi przychodzili i odchodzili41. M. Dutton uważa, że Walter ok. 1155 r. mógł zostać sekretarzem opata, a więc i jego stałym towarzyszem, ponieważ niemal wszystkie jego utwory (z wyjątkiem Speculum caritatis i niektórych dzieł historycznych) powstawały właśnie wtedy. Był to czas, kiedy Aelred zapadł poważnie na zdrowiu i częściej musiał przebywać w domu, zajmując się głównie, ku uciesze mnichów, sprawami duchowymi klasztoru. Wtedy też właśnie mogły powstać wszystkie jego duchowe utwory, w dużej mierze dyktowane Walterowi ${ }^{42}$.

Prof. M. Dutton argumentuje, że wnikliwsza analiza Vita Aelredi może odsłonić wyraźniejszy portret jego autora. Już na początku utworu Walter stawia wyraźnie siebie $\mathrm{w}$ jego centrum ${ }^{43}$, będąc wręcz obsesyjnie zajęty bardziej sobą niż Aelredem ${ }^{44}$. Na każdym niemalże kroku towarzyszy on wszystkim narracjom, eksponując swoje własne opinie na różne tematy poruszane w utworze, swoje uczucia, irytacje, zadowolenie z siebie, gadulstwo, wrażliwość na piękno, oddanie się życiu cysterskiemu, a nade wszystko miłość do

\footnotetext{
${ }^{37}$ Por. tamże, s. XVI-XVII.

${ }^{38}$ Por. tamże, s. XXVII.

${ }^{39}$ Por. Dutton, Introduction, s. 9-19.

${ }^{40}$ Por. Walter Daniel, Vita Aelredi 27, ed. Powicke, s. F. 68a: „Siquidem scripta illius ostendunt sufficienter qualiter sit locutus, que manu mea et labore memorie posterorum reseruate sunt".

${ }^{41}$ Por. Dutton, Introduction, s. 9-10.

${ }^{42}$ Por. tamże, s. 13.

${ }^{43}$ Por. Walter Daniel, Vita Aelredi 1.

${ }^{44}$ Por. Dutton, Introduction, s. 11. Zob. Walter Daniel, Vita Aelredi 1, ed. Powicke, s. F. 63c: „Ad quid faciam miser inter has ambages discriminis, que sic latera mea stringunt et constringunt affectum et uoluntatem retundunt? Nam ille quidem plus cupit quam potest, hec uera tantum tenere suadet”.
} 
Aelreda ${ }^{45}$. Niejednokrotnie wykazuje się też ekstrawagancją ${ }^{46}$ i domaga się uznania specjalnej relacji przyjaźni z opatem. Tak było np. z dziełami Aelreda, które dzięki ,pracy jego własnych rąk” zostały zachowane dla potomności ${ }^{47}$, albo kiedy opisując ból i cierpienie opata, dokładnie wiedział, co on czuje i myśli ${ }^{48}$. Odczuwa wyraźną satysfakcję, dającą mu publiczny i szerszy rozgłos, z faktu przyjaźni, jaką darzy go Aelred, który sam to poświadcza w dialogu o przyjaźni, czyniąc go jednym z jej interlokutorów. Chce w ten sposób wyrazić prawdę, że Aelred dyskutował $\mathrm{z}$ nim na ten temat ${ }^{49}$. I nic dziwnego, biorąc pod uwagę to, że Walter był jego skrybą i pielęgniarzem, podczas lat choroby musiał zapewne regularnie $\mathrm{z}$ nim rozmawiać i dyskutować na wiele tematów teologicznych. To musiało ich wzajemnie zbliżyć w sensie zawiązania pewnej formy przyjaźni ${ }^{50}$. Nie można $\mathrm{w}$ tym miejscu zapominać o jego umiłowaniu życia zakonnego, które opisuje w superlatywach, szczególnie pod rządami Aelreda. Wszystko to nie wyklucza arogancji Waltera i grubiaństwa w stosunku do innych, którzy nie zgadzali się z jego punktem widzenia. Widać to choćby w sposobie traktowania swej opozycji, której we wspomnianym już Liście do Maurycego zarzuca literacką ignorancję i intelektualne niziny. Zresztą dokładnie te jego cechy osobowości: grubiaństwo, gadatliwość, egocentryzm, wybuchy gniewu, znamionują osobę Waltera z dialogów Aelreda o przyjaźni duchowej, wskazując, że chodzi właśnie o tę samą osobę $e^{51}$.

Bardziej jednak od autora są ważne motywy powstania samego utworu, ponieważ one thumaczą i poniekąd usprawiedliwiają jego charakter hagiograficzny. Można je wywnioskować z kontekstu powstałego dzieła oraz analizy krytycznej i teologicznej jego tekstu.

3. Przyczyny powstania Vita Aelredi. Z tekstu Vita Aelredi, a właściwie ze wstępnego listu wprowadzającego do Żywota, dowiadujemy się, że ogólną przyczyną jego napisania była niedawna śmierć Aelreda, trzeciego opata angielskiego opactwa w Rievaulx:

${ }^{45}$ Por. Dutton, Introduction, s. 12. Zob. Walter Daniel, Vita Aelredi 12; 26; 27; 30; 33; 39; 43, itp.

${ }^{46}$ Por. np. Walter Daniel, Vita Aelredi 12, ed. Powicke, s. F. 65c: „Ut sua ex parte diximus” (Jak w swoim czasie powiedziałem); tamże 27, ed. Powicke, s. F. 68a: „Set de hiis satis (Ale dosyć już tego)".

${ }^{47}$ Por. tamże 27, ed. Powicke, s. F. 68a: „Siquidem scripta illius ostendunt sufficienter qualiter sit locutus, que manu mea et labore memorie posterorum reseruate sunt".

${ }^{48}$ Por. tamże 56. Zob. Dutton, Introduction, s. 13.

${ }^{49}$ Por. tamże 41, ed. Powicke, s. F. 70b: „Post quas edidit tres libros de spirituali amicicia sub dialogo. In quorum primo Iuonem supradictum se interrogantem introduxit et me in sequentibus loquentem secum ordinauit".

${ }^{50}$ Por. Dutton, Introduction, s. 13-16.

${ }^{51}$ Por. tamże, s. 14-15. 
„Niedawna śmierć naszego ojca jest jak mocny przymus twojego życzenia, które kieruje nas naprzód, wymaga posłuszeństwa i nakazuje wypełnianie twoich wskazówek"52.

M. Dutton jednakże, na podstawie tego samego fragmentu, sugeruje, iż obwieszczenie tej śmierci zaraz na samym początku może wskazywać, że większa część dzieła mogłaby powstać jeszcze za życia opata, szczególnie w ostatnich miesiącach jego choroby, o czym nawet mógł wiedzieć opat H. Wtedy sam wstępny list powstałby później (po śmierci opata) niż reszta utworu, co też by tłumaczyło dysproporcję w opisie ostatnich czterech lat życia Aelreda, które zajmują większą część listu ${ }^{53}$. Bez względu na to, kiedy została rozpoczęta praca nad spisaniem żywota opata, ważny był tu moment jego śmierci, bo to on ostatecznie zadecydował o sfinalizowaniu całego utworu.

Thomas J. Heffernan podaje historyczno-teologiczną interpretację faktu tej śmierci, wierząc, że właśnie taka idea przyświecała Walterowi. Uważa, że postać Aelreda była o tyle ważna, że należała do pokolenia pierwszych cystersów Anglii, budujących tradycję monastyczną Europy, obok lub wraz z wielkim Bernardem z Clairvaux, którego zmarły znał osobiście. Mnisi pod jego rządami doznali dobrodziejstwa, widząc jego ogromny wpływ na życie polityczno-społeczne królestwa, w którym żyli, jak również pozytywne zmiany materialno-duchowe życia monastycznego emanującego z Rievaulx. Przeczuwali, że śmierć opata oznaczała zatem wielkie przejście. Wierzyli, że moment śmierci był wielkim wydarzeniem historycznym, bo na ich oczach odchodziła swoista legenda pierwszej generacji angielskich cystersów. Płakali po stracie wielkiego duchowego nauczyciela, który nie tylko zasługiwał na świętość, ale ją reprezentował, bo był fizycznym, namacalnym znakiem obecności Chrystusa w ich klasztorze, a tym samym niejako spełnieniem biblijnej obietnicy zbawienia. Wraz z momentem jego śmierci mogli obawiać się, że będa pozbawieni duchowego przewodnictwa i jakby światła oświetlającego do tej pory ich drogę ${ }^{54}$. Według Heffernana, potwierdzeniem tego mogą być m.in. słowa Daniela, w których porównuje odejście opata, zgodnie z tradycją pochwalną, do zniknięcia porannego słońca:

„Nasz ojciec umarł. Zniknął z naszego świata jak poranne światło słońca i wiele serc pragnie, aby to wielkie światło oświeciło i zalało swoim blaskiem pamięć przyszłych pokoleń oraz tych, którzy jeszcze żyją, dla których świeciło całym swoim blaskiem" 55 .

${ }^{52}$ Walter Daniel, Vita Aelredi 1, ed. Powicke, s. F. 63c: „Ad hanc nichilominus tuam intentacionem accredit et imminet recens patris obscessio que nos ultro prodire prouocat, obedire iubet, et tuis ammonet parere mandatis".

${ }^{53}$ Por. Dutton, Introduction, s. 76 i 78.

${ }^{54}$ Por. T.J. Heffernan, Sacred Biography. Saints and Their Biographers in the Middle Ages, New York - Oxford 1992, 72-73.

${ }^{55}$ Walter Daniel, Vita Aelredi 1, ed. Powicke, s. F. 63c: „Quoniam quidem pater noster obiit et 
To właśnie dlatego m.in. Walter Daniel wystylizował postać Aelreda na wielkiego świętego mnicha ${ }^{56}$, co widać szczególnie w opisie jego śmierci, gdzie np. dobiera biblijne i ewangeliczne słowa (,W ręce twoje Panie, powierzam ducha mojego", por. Łk 23, 46; Dz 7, 59; Ps 30, 6; Rdz 2, 7) i wkłada je w usta umierającego Aelreda, albo opisuje jaśniejący blask, jaki emanował z jego martwego ciała, kiedy było ono obmywane i balsamowane. W pierwszym przypadku, idąc za wzorem Jezusa Chrystusa i św. Szczepana, chciał pokazać opata z Rievaulx w roli templum Dei, w której był Duch Boży, zawsze kierujący jego świętym życiem, a szczególnie obecny w momencie śmierci ${ }^{57}$. $\mathrm{W}$ drugim przypadku, zastosował schemat hagiograficzny przybrany $\mathrm{w}$ retoryczną hiperbolę zapożyczoną z opisu śmierci św. Marcina z Tours autorstwa Sulpicjusza Sewera ${ }^{58}$.

Bardzo wymowne pod tym względem są słowa z jego Listu do Maurycego:

„Jak to możliwe, by martwe ciało Aelreda nie świeciło, kiedy było obmywane? To było światło dla nas wszystkich. I to jak? Świeciło ono bardziej niż czerwony granat. A wydzielany zapach wydawał się dla nas czymś więcej niż wonią kadzidła; wszyscy byliśmy pod wrażeniem. I nic dziwnego, ponieważ nigdy wcześniej w życiu nie zdarzyło się, by (tak) uczciwy i prosty człowiek mieszkał w ciele tak jasnym jak wtedy, kiedy leżał martwy. Mówię bez cienia fałszu, że nigdy nie widziałem tak jasnego ciała w żadnym człowieku, martwym lub żywym" 59 .

W całym tym zabiegu kryła się intencja Daniela, by unaocznić mnichom z Rievaulx, że byli oni świadkami śmierci kogoś wyjątkowego, świętego, w którym prawdziwie zamieszkiwał Duch Boży i który teraz umierał w chwale, czego znakiem było jaśniejące blaskiem jego ciało, na wzór wielkiego św. Marcina $\mathrm{z}$ Tours ${ }^{60}$.

Śmierć Aelreda, która niejako z natury domagała się spisania jego wyjątkowego żywota i samego momentu jego odejścia ku pamięci następnych pokoleń mnichów, nie była jednak główną przyczyną powstania Vita Aelredi.

quasi lux matutina euanuit e terra nostra et multorum animo insidet ut radius tanti luminis refundatur ad memoriam et illuminationem futurorum, immo eciam et quorundam presencium quibus et ipsum lumen emicuit in fulgore suo". Zob. Heffernan, Sacred Biography, s. 73, nota 4.

${ }^{56}$ Por. Heffernan, Sacred Biography, s. 74.

${ }^{57}$ Por. tamże, s. 73 i 83-87.

${ }^{58}$ Por. tamże, s. 103-122.

${ }^{59}$ Walter Daniel, Epistula ad Mauricium 77, ed. Powicke, s. F. 62d: „Alredi corpus num mihi non luxit cum lauaretur defunctum? Vere lux nobis omnibus qui affuimus. At quomodo? Plus multo quam si carbunculus affuisset. Quod eciam super adorem thuris redolebat, sic nobis uisum est, sic sensimus omnes. Nec mirum. Nunquam enim antea in uita sua carnem sic candidam gessit pulcher ille et decorus quomodo quando iacebat defunctus. Dico sine scrupulo mendacii, nuncquam ego tam candidam carnem uidi alterius cuiuslibet uiui uel defuncti".

${ }^{60}$ Szerzej na ten temat zob. R. Groń, Śmierć Aelreda z Rievaulx - między teorią a rzeczywistością, VoxP 26 (2006) t. 49, 195-207. 
Autorowi bowiem przyświecała naczelna idea ukazania chrześcijańskich cnót wielkiego angielskiego cystersa, które należało naśladować, oraz cudów, jako znaków działania w nim i przez niego Ducha Bożego ${ }^{61}$. W istocie, to właśnie one stanowią treść każdego świątobliwego życia, dla którego wyrażenia najlepszy był styl hagiograficzny. Z tekstu Vita dowiadujemy się, że święty żywot Aelreda został spisany ze względu na to, iż miał właśnie dostarczać argumentów przemawiających za tą świętością. Opat H. zlecający to zadanie Walterowi Danielowi, nie tylko chciał utrwalić pamięć o zmarłym Aelredzie, ale także, by była to dobra pamięć na miarę świętego opata. Dlaczego mu tak na tym zależało?

Analiza wymienionych utworów Waltera wskazuje, że znana nam skądinąd szeroko zakrojona działalność publiczna Aelreda i jego sława dobrego administratora, dyplomaty, arbitra, zapraszanego kaznodziei, doradcy i przyjaciela biskupów, prałatów, królów, książąt, szlachty, a więc bywalca ich świeckich dworów oraz w ogóle aktywność światowa opata, nie wszystkim w klasztorze i poza nim się podobała ${ }^{62}$. Dlatego mogła być tu ona specjalnie pominięta, a uwydatniona raczej jego świątobliwa i mądra działalność wewnątrz klasztoru i to ta raczej w ostatnich latach życia, kiedy Aelred rzeczywiście przebywał w klasztorze, z powodu choroby. Niektórzy widzieli go też jako pysznego i zbyt ambitnego, co dało się zaobserwować podczas jego wyboru na opata, po rezygnacji Maurycego ${ }^{63}$. Po śmierci Aelreda, jego następca, opat Sylwan, zdawał się mieć kłopoty z utrzymaniem dyscypliny w klasztorze, z racji zbyt pobłażliwego traktowania przez poprzednika mnichów i faworyzowania niektórych z nich. Na pewno nie wszyscy byli z tego zadowoleni ${ }^{64}$.

W podsumowaniu tego można stwierdzić za M. Dutton, że Vita Aelredi została spisana na prośbę opata H., w większości być może jeszcze przed śmiercią Aelreda, ale dokończona zaraz po niej, mając za zadanie opisać wszystko, co ewentualni przeciwnicy mogliby próbować zatuszować lub przedstawić na jego niekorzyść. Świadczy o tym również wspomniany List do Maurycego, z którego wynika, że zarówno Maurycemu jak i dwóm cytowanym przez niego prałatom, zależało na zniesławieniu Aelreda ${ }^{65}$. Dlatego jeszcze przed nimi należało go przedstawić w pozytywnym świetle, uwypuklając jego cnoty i duchowy styl życia.

${ }^{61}$ Walter Daniel, Vita Aelredi 1-2.

${ }^{62}$ Por. Powicke, Introduction, s. LI-LII; Dutton, Introduction, s. 8.

${ }^{63}$ Por. Walter Daniel, Vita Aelredi 33-34.

${ }^{64}$ Por. Powicke, Introduction, s. LII i LXIV. Brian P. McGuire (Friendship and Community. The Monastic Experience 350-1250, Kalamazoo 1988, 337; Brother and Lover. Aelred of Rievaulx, New York 1994, 130-139) twierdzi nawet, że z tego właśnie powodu tj. zaufania bardziej moralnej i duchowej sile przyjaźni, którą głosił i praktykował, niż przestrzegania dyscypliny zakonnej, miał on być specjalnie wymazywany z pamięci swych kolejnych następców, poczynając już od Sylwana.

${ }^{65}$ Por. Dutton, Introduction, s. 77-78. 
M. Dutton uzasadnia to w następujący sposób ${ }^{66}$. Najpierw zauważa, że nacisk Waltera jest położony na to, by poprzez jego utwór ukazać ,zdumiewającą świętość" Aelreda ${ }^{67}$. Autor posługuje się przy tym modelem hagiograficznym, co znaczy, że mamy tu do czynienia z tzw. „świętą biografią”. Sformułowanie to jest autorstwa Heffernana i oznacza ,tekst narracyjny życia świętego napisany przez członka wspólnoty wiary" ${ }^{\prime 6}$. Jako taki, utwór ten miał ukazać opata jako męża Bożego, jednak nie - jak w przypadku Bernarda z Clairvaux - w celu tworzenia jego kultu lub wszczęcia kanonizacji. Chodziło bardziej o zachowanie pamięci o Aelredzie wśród tych, którzy go już znali i kochali, jak i tych, którzy mogli go nie znać. Bezpośrednią jednak przyczyną spisania Vita było wspomniane już wyżej zbicie ewentualnej krytyki ludzi nieprzychylnych opatowi, którzy zarzucali mu pychę, ambicje, większe zaangażowanie w sprawy świata, niż zajmowanie się potrzebami wspólnoty, reguła i cysterskim życiem w kontemplacji; którzy mogli stanowić frakcję w klasztorze czekającą na jego śmierć, by móc go wreszcie bezkarnie zniesławićc ${ }^{6}$. Dlatego Vita jest apologią Aelreda mającą zachować pamięć o nim, jako o troskliwym opacie, który kochał i płakał nad swoimi duchowymi synami „niczym matka”, przyczyniał się do ekonomicznego wzrostu klasztoru, intensyfikacji życia religijnego $\mathrm{w}$ dwóch podległych mu opactwach ${ }^{70}$ oraz przez którego - jako człowieka uduchowionego - zbawiał i uzdrawiał sam Bóg ${ }^{71}$. Z drugiej strony, z racji wyżej wspomnianych oskarżeń, Walter - o ile tylko mógł - świadomie omijał publiczną szeroko zakrojoną działalność opata, podkreślając bardziej jego całkowite poświęcenie się dla swych duchowych synów w klasztorze. Jego cudowną świętość natomiast przedstawiał jako przejaw życia związanego z pokorą i dziełami miłości ${ }^{72}$.

4. „Święta biografia” Aelreda z Rievaulx. M. Dutton, posiłkując się badaniami Donalda Weinsteina i Rudolpha M. Bell ${ }^{13}$, określa charakter opisywanej przez Waltera świętości Aelreda, pokazując dokładnie, o co mu chodziło. Zgodnie z zamiarem autora, świętość ta miała polegać głównie na podaniu innym mnichom przykładu cnotliwego życia, a nie na spektakularnej działalności cudotwórczej ${ }^{74}$. Dlatego dziwi go zarzut stawiany później przez wspomnianych prałatów z Listu do Maurycego, kwestionujący niektóre opisane przez niego w Vita cechy świątobliwego życia Aelreda, głównie jego

\footnotetext{
${ }^{66}$ Por. tamże.

${ }^{67}$ Por. Walter Daniel, Vita Aelredi 1.

${ }^{68}$ Heffernan, Sacred Biography, s. 15, thum. własne.

${ }^{69}$ Por. Dutton, Introduction, s. 72-73 i 78-79.

${ }^{70}$ Por. Walter Daniel, Vita Aelredi 36-37.

${ }^{71}$ Por. Dutton, Introduction, s. 75.

${ }^{72}$ Por. tamże, s. 76-78.

${ }^{73}$ Por. D. Weinstein - R.M. Bell, Saints and Society, Chicago 1982, 102-120.

${ }^{74}$ Por. Walter Daniel, Vita Aelredi 2.
} 
czystość w okresie młodości ${ }^{75}$, a przede wszystkim zdziałane przezeń cuda ${ }^{76}$. Walter w swej apologii Aelreda ukazuje te cuda bardziej jako wypadkowa jego chrześcijańskich cnót, głównie pokory, modlitwy i miłości, aniżeli nadprzyrodzone ingerencje Boże. Było to zgodne zresztą z ogólną linią cysterskiej duchowości zapoczątkowanej przez Bernarda z Clairvaux ${ }^{77}$. Również stracone przez Aelreda dziewictwo w okresie przed wstąpieniem do klasztoru nie było niczym nowym w tamtych czasach, kiedy na ogół przyjmowano dorosłych kandydatów po wcześniejszej inicjacji seksualnej. Widać fakt ten musiał być powszechnie znany w przypadku Aelreda, skoro Walter wcale tego nie zanegowal $^{78}$, dając niejako do zrozumienia, że po nawróceniu nie jest ono przeszkodą do uzyskania świętości.

Opisywana przez Waltera świętość opata z Rievaulx, polegająca na monastycznym życiu w cnotach chrześcijańskich, głównie pokory i miłości, przebija się przez wszystkie strony Vita. Autor wykorzystuje przy tym niektóre zdarzenia z życia swego bohatera, szczególnie te bliższe mu, jednak są one drugorzędne i często nie trzymają się porządku chronologicznego. W Vita jest wiele braków biograficznych, nie ma prawie żadnych wiadomości na temat jego rodziny i wczesnych lat życia, jest wiele niewyjaśnionych zdarzeń, szczególnie z okresu młodości, dotyczących jego świeckiej edukacji, kariery i przyjaźni, brak wytłumaczenia okoliczności i czasu jego przebywania na dworze szkockim króla Dawida oraz wstąpienia do klasztoru, już nie mówiąc o niemalże całkowitym pominięciu aspektu życia publicznego na rzecz państwa, Kościoła i zakonu, w trakcie jego posługiwania opackiego, najpierw w Revesby, a potem w Rievaul ${ }^{79}$. Wszystkich tych wiadomości trzeba po prostu szukać w innych źródłach. Vita Aelredi jako święta biografia w swej budowie jest podporządkowana wykazaniu „zadziwiającej świętości” Aelreda, czyli ukazaniu jego wzrastania w pokorze, miłości i pobożności, tj. zdobywaniu zwyczajnej świętości w ramach życia monastycznego.

Już struktura utworu podkreśla, co w życiu Aelreda wydaje się dla Waltera najważniejsze. Z sześćdziesięciu rozdziałów tylko trzy mówią o życiu naszego bohatera przed nawróceniem (1-3), jeden koncentruje się na wzroście jego pragnienia wstapienia do klasztoru, kiedy jeszcze przebywał na dworze szkockim (4). Następne trzy rozdziały opowiadają o jego nawróceniu (5-7). Dwadzieścia trzy są poświęcone życiu w klasztorze w okresie od 1134 do 1157 r., kiedy to wstapił do Rievaulx, został mistrzem nowicjatu, opatem w Revesby i Rievaulx (8-30). Druga połowa dzieła (30 rozdziałów) opisuje ostatnie dziesięć lat życia

${ }^{75}$ Por. tenże, Epistula ad Mauricium 76; tenże, Vita Aelredi 4.

${ }^{76}$ Por. tenże, Epistula ad Mauricium 66-70.

${ }^{77}$ Por. A. Bredero, Bernard of Clairvaux. Between Cult and History, Edinburgh 1996, 72-73;

R. Groń, Śmierć Bernarda z Clairvaux w świetle 'Vita prima', VoxP 28 (2008) t. 52/1, 273.

${ }^{78}$ Szerzej na ten temat zob. J. Leclercq, Monks and Love in Twelfth-Century France, New York 1987; Dutton, Introduction, s. 71

${ }^{79}$ Por. Walter Daniel, Vita Aelredi 42. Zob. Dutton, Introduction, s. 49-50. 
Aelreda, gdy został zwolniony z niektórych obowiązków opackich z powodu choroby, z czego siedemnaście rozdziałów relacjonuje ostatnie cztery lata (3147), a trzynaście - ostatni rok życia i jego śmierć (48-60). M. Dutton zauważa, że w ramach tej struktury Walter rozwija podstawowe tematy swego dzieła: świętość Aelreda; sposób zdobywania jego pobożności, cnót cierpliwości i miłości, mądrości, które miały potem swe odzwierciedlenie w budowaniu wspólnoty zakonnej; pisanie listów, traktatów duchowych i homilii; czynienie cudów i umieranie na wzór Chrystusa (imitatio Christi) ${ }^{80}$. I chociaż na przestrzeni całego utworu Walter podkreśla wiele aspektów cnotliwego życia opata, to jednak zawsze powraca do dwóch cnót, które od początku konstytuuja jego świętość: pokory i miłości.

Owocem jego świętości miał być nie tylko wzrost materialno-duchowo-liczebny Revesby i Rievaulx, ale też jego płodność jako pisarza i przewodnika duchowego oraz cuda, których dokonał. Jego zdolność cudotwórcza (w rzeczywistości siła modlitwy w intencji mnichów) wzmagała się wraz ze wzrostem duchowym (w pokorze i miłości), poprzez który objawiała się moc działającego Boga: w Revesby miały miejsce dwa uzdrowienia, zaś w Rievaulx - cztery ${ }^{81}$. W istocie miały one niewiele wspólnego ze zjawiskową cudownością, a więcej z modlitwą i dziełami miłosierdzia. Dopiero w ostatnich czterech latach życia, pośród cierpienia, doznał kontemplacji Bożych tajemnic oraz wizyt anielskich gości ${ }^{82}$. Śmierć uwolniła opata z cierpienia i pozwoliła mu wejść do chwały błogosławionych ze słowami Chrystusa na ustach: „W Twoje ręce powierzam ducha mego", a jego ciało jaśniało blaskiem niebiańskiej chwały ${ }^{83}$.

Lektura Listu do Maurycego uściśla jeszcze bardziej stanowisko Waltera odnośnie do traktowania cudów Aelreda jako znaków jego „zadziwiającej świętości”, tj. pobożności, pokory i miłości, względem potrzebujących braci. $\mathrm{W}$ ostrej polemice $\mathrm{z}$ dwoma prałatami autor jeszcze raz podkreśla zasługi cnotliwego życia Aelreda przewyższające wszelkie nadnaturalne moce, które mogą czynić również źli ludzie. Na tym tle same cuda jawią się jako wypadkowa jego cnotliwego życia ${ }^{84}$. Dlatego do wymienionych wcześniej w Vita cudów dodał cztery nowe, mające wzmocnić to przekonanie. Odpowiadają one poszczególnym okresom życia naszego bohatera: niemowlęctwa, dzieciństwa, młodości i wieku dojrzałego ${ }^{85}$.

Powicke celnie podsumował hagiograficzne cechy świętej biografii Aelreda, mimo iż nie zauważył w niej niczego oryginalnego, czego nie byłoby w innych średniowiecznych utworach tego rodzaju. Mają one za zadanie przy-

\footnotetext{
${ }^{80}$ Por. Dutton, Introduction, s. 51.

${ }^{81}$ Por. tamże, s. 58.

${ }^{82}$ Por. Walter Daniel, Vita Aelredi 50-51 i 52-54.

${ }^{83}$ Por. tamże 62. Zob. Dutton, Introduction, s. 66.

${ }^{84}$ Por. Walter Daniel, Epistula ad Mauricium 78 i 81. Szerzej na ten temat zob. Powicke, Introduction, s. LXXVIII-LXXXI; Dutton, Introduction, s. 66-74.

${ }^{85}$ Por. Walter Daniel, Epistula ad Mauricium 71-75.
} 
wołać wzorce hagiograficzne zaczerpnięte z różnych znanych źródeł, głównie Biblii (Ewangelii) i żywotów niektórych znanych świętych: ponadnaturalne światło jaśnieje nad głową dzieciątka zwiastując narodziny kogoś ważnego ${ }^{86}$; dziecko już prorokuje ${ }^{87}$; młodzieniec zachowuje cnotliwe życie ${ }^{88}$; moc uzdrowienia poprzez rzeczy należące do świętego ${ }^{89}$; wizje profetyczne ${ }^{90}$, wizyty anielskie $^{91}$; żywioły faworyzują świętego, jak to ma miejsce w Dundrennan, kiedy deszcz padający przez wielką wyrwę w dachu nie zalewa tylko jego łoża ${ }^{92}$, surowa asceza świętego i większa wyrozumiałość dla innych ${ }^{93}$, przykładna śmierć, a po niej ciało świętego mimo długiej choroby i cierpienia wygląda świeżo, jak u dziecka ${ }^{94}$. Zrozumienie tej specyfiki hagiograficznej utworu pozwala nie tylko wyłuskać prawdziwe dane biograficzne, ale również wskazać na źródła Vita Aelredi.

5. Źródła Vita Aelredi. Wcześniejsze uwagi dotyczące autora Vita Aelredi, jako długoletniego mnicha przebywającego w klasztorze zarządzanym przez Aelreda, jego rola skryby i pielęgniarza, który spędzał z opatem ostatnie lata życia, przesiadywał z nim długie godziny i spisywał jego dzieła, wyuczona inteligencja oraz cechy charakteru Waltera, pozwalają wyciagnąć wniosek, że to właśnie on jest głównym źródłem dla swego utworu. Najpierw jest on źródłem formalnym, w sensie formy przekazu, bo jak by nie patrzeć na jego dzieło, odbite jest w nim piętno samego autora przekonanego o świętości swego bohatera. Jak zauważa M. Dutton, trudno oddzielić opisywane wydarzenia z życia Aelreda od biogramu Waltera, od jego punktu widzenia ${ }^{95}$. Bardzo często, oprócz podanych faktów, występują jego własne opinie, komentarze, krytyki, sugestie, burzliwe reakcje zabarwione różnymi emocjami. W połączeniu z jego egocentryczną postawą ma się czasem wrażenie, że Vita jest bardziej autobiografią Waltera niż świętą biografią Aelreda. W każdym razie jest to święta biografia stworzona $\mathrm{z}$ perspektywy biografa. Trzeba też pamiętać, że to Walter dobiera literackie (hagiograficzne) formy wyrazu, chcąc pokazać swego bohatera w roli świętego i cnotliwego opata; on jest reporterem, interpretatorem oraz krytykiem literackim, który ocenia prozę życia opata; on jest wreszcie pielęgniarzem, który wie, co opat czuje, jak reaguje w momencie bólu i konania; on jest żałobnikiem, który obmywa jego ciało i całuje jego sto-

\footnotetext{
${ }^{86}$ Por. tamże 71.

${ }^{87}$ Por. tamże 72.

${ }^{88}$ Por. tenże, Vita Aelredi 4; tenże, Epistula ad Mauricium 76.

${ }^{89}$ Por. tenże, Vita Aelredi 32.

${ }^{90}$ Por. tenże, Epistula ad Mauricium 72.

${ }^{91}$ Por. tenże, Vita Aelredi 50.

${ }_{92}$ Por. tenże, Epistula ad Mauricium 74.

${ }_{93}$ Por. tenże, Vita Aelredi 25.

${ }^{94}$ Por. tamże 62. Zob. Powicke, Introduction, s. LXXVI.

${ }^{95}$ Por. Dutton, Introduction, s. 17-18.
} 
py po śmierci. Jak zauważa Dutton, przedstawienie życiorysu Aelreda przez Waltera jest prawie całkowicie poświadczone przez stałą obecność autora, do tego stopnia, że życie opata Rievaulx bez zdobytej dzięki naocznej obserwacji wydarzeń wiedzy Waltera, całkowicie przekonanego o świętości swego bohatera, praktycznie nie istnieje. Pod tym względem Walter, w sensie jego własnego doświadczenia, sam dla siebie jest źródłem ${ }^{96}$.

Z powyższego wynika, że Walter jest również dla siebie źródłem w sensie materialnym, to znaczy, że z reguły był on świadkiem wielu opisywanych wydarzeń, choć podawał ich własną interpretację. Z drugiej strony, jego nieobecność jako świadka może tłumaczyć brak innych informacji o Aelredzie, jak na przykład o szerszej działalności opata poza klasztorem; pomijając już to, że właściwie te wydarzenia go nie interesowały. Nie dziwi natomiast zarejestrowana wszechobecność Waltera w ostatnich latach życia opata, podczas jego choroby i umierania, gdyż niewątpliwie był on tego świadkiem.

Jest również bezdyskusyjne, że sam opat był dla biografa źródłem wiedzy. Oczywiście trudno ją było zweryfikować, bo Aelred już nie żył, kiedy ukazała się Vita. Musimy więc zakładać jego prawdomówność. Walter nie raz zaznacza, że opat był źródłem jego informacji dotyczących wczesnych lat jego życia. Dotyczy to: opowiadania o nawróceniu; wczesnych latach spędzonych na dworze króla Dawida; przygody z zazdrosnym szlachcicem ${ }^{97}$; przedstawienia wczesnej działalności pisarskiej poświęconej człowieczeństwu Chrystusa $^{98}$; pierwszego cudu modlitwy, związanego z nowicjuszem, który opuścił Rievaulx, a następnie powrócił do klasztoru ${ }^{99}$. Rozdział o Aelredzie jako mistrzu nowicjatu zakłada późniejszą wiedzę Waltera nabytą od Aelreda lub zaczerpniętą z jego utworów. Na przykład w Speculum caritatis autor wychwala jego lotny umysł i prostotę retoryki, jakkolwiek zna je dopiero z perspektywy ostatnich siedemnastu, a właściwie czterech lat życia, kiedy z nim stale przebywał ${ }^{100}$.

Część wiedzy Waltera mogła pochodzić od świadków życia Aelreda, np. od ojca Waltera Daniela. Walter sam okazyjnie wspomina starszego Szymona, opata z Sartis, który był jego mistrzem nowicjatu. Od niego zapewne musiał zaczerpnać wiadomości o jego życiu modlitwy, kontemplacji i pracy ${ }^{101}$. Biograf wymienia też wychowanków nowicjatu Aelreda ${ }^{102}$, a także pewnego zakonnika, który miał widzenie jego błogosławionego stanu przed śmiercią ${ }^{103}$. Pogrzeb opata pokazuje, że byli na nim również Richard - opat z Fountains i Roger -

\footnotetext{
${ }^{96}$ Por. tamże, s. 17-18.

${ }^{97}$ Por. Walter Daniel, Vita Aelredi 5-7; tenże, Epistula ad Mauricium 67.

${ }^{98}$ Por. tenże, Vita Aelredi 10 i 19.

${ }_{99}^{9}$ Por. tamże 24; tenże, Epistula ad Mauricium 67.

${ }^{100}$ Por. Dutton, Introduction, s. 47.

${ }^{101}$ Por. Walter Daniel, Vita Aelredi 16-18.

102 Por. tamże 23.

${ }^{103}$ Por. tamże 52-54.
} 
opat z Byland, stając się naturalnymi źródłami tych i innych wiadomości. List do Maurycego, z racji swego charakteru apologetycznego, przywołuje wielu innych świadków cudów opisanych przez Waltera oraz ich beneficjentów ${ }^{104}$. Biorąc pod uwagę charakter hagiograficzny utworu, źródłami dla niego są też inne utwory hagiograficzne, z których autor czerpał swe informacje: Ewangelie, Vita Martini Sulpicjusza Sewera ${ }^{105}$, oraz niektóre schematy hagiograficzne ${ }^{106}$.

6. Pozostałe źródła biografii Aelreda. Vita Aelredi i związany z nią List do Maurycego uchodzą za główne i najbardziej kompletne istniejące źródło biografii Aelreda z Rievaulx, ale jako takie nie są one biograficzne we współczesnym rozumieniu tego słowa, gdzie zwraca się uwagę na faktyczne detale z całego życia opisywanej osoby. Vita Aelredi, należąc do hagiograficznego gatunku świętej biografii, traktuje te detale wybiórczo jako punkty styczne $\mathrm{z}$ daną osoba, punkty odniesienia, by ukazać jej naczelny cel, a mianowicie, świętość, i to właściwymi dla niej formami wyrazu. W tej perspektywie, Vita Aelredi, będąc wprawdzie głównym źródłem biografii, sama domaga się korekty i uzupełnienia o te dane biograficzne, które się w niej nie znalazły, bo nie pasowały do założonego zamiaru, lub zostały zniekształcone tak, by odpowiadały założonej odgórnie idei świętości. Zrozumienie norm hagiografii pozwala więc, z jednej strony prawidłowo ukierunkować biografię danej osoby, czasem nawet podważyć autorytet i pewność hagiografa, a z drugiej, zakłada uzupełnienie jej sylwetki o rzetelne badania historyczno-literackie. Chodzi więc, o poszukiwanie logicznych dróg zrozumienia wydarzeń z życia Aelreda, biorąc pod uwagę hagiograficzną specyfikę utworu, a także koniecznie posiłkując się innymi źródłami z historii i literatury tamtych czasów i dziełami samego bohatera $^{107}$. Dlatego, oprócz Vita Aelredi i Listu do Maurycego, których elementy biograficzne należy odczytać w świetle badań hagiograficznych, trzeba uwzględnić pozostałe źródła, by móc uzyskać pełny i w miarę obiektywny obraz życia Aelreda z Rievaulx.

M. Dutton tematowi temu poświęciła specjalny rozdział, pokazując, na czym polega spreparowana hagiograficznie przez Waltera Daniela postać naszego bohatera ${ }^{108}$. Wspominaliśmy już o tym wcześniej, lecz teraz warto to powtórzyć w nowym kontekście. Aelred jawi się w nim jako cierpliwy i kochający mnich i opat, uzdrowiciel, nauczyciel i wizjoner, poprzez którego objawia się moc Boża wyrażona w jego modlitwie i cudach. Jako taki, jest nie tyle figurą historyczną dwunastowiecznego Yorkshire, co mężem Bożym. Brak tu

\footnotetext{
${ }^{104}$ Por. tenże, Epistula ad Mauricium 67-69.

${ }^{105}$ Por. tamże 77.

${ }^{106}$ Por. tenże, Vita Aelredi 62. Zob. Dutton, Introduction, s. 47-49; Powicke, Introduction, s. LXXVI-LXXVII.

${ }^{107}$ Szerzej na ten temat zob. Heffernan, Sacred Biography, s. 35-36; Dutton, Introduction, s. $85-86$.

${ }^{108}$ Por. Walter Daniel, Vita Aelredi, 45-46; Dutton, Introduction, s. 79-86.
} 
wielu informacji dotyczących jego prawdziwej historii życia, a te, które zostały zanotowane w Vita są niepełne lub mylne: pominięte jest prawie całe jego dzieciństwo i młodość, już nie mówiąc o jego rodzinie; niezrozumiały jest historyczno-społeczno-religijny kontekst jego znalezienia się na dworze króla Dawida i później w klasztorze Rievaulx, czyli wyjaśnienie jego kariery świeckiej i zakonnej; brak jest wzmianek na temat jego przyjaźni z młodości oraz pełnej listy jego utworów; prawie nic nie wiadomo, co robił na dworze królewskim, jako mistrz nowicjatu, jak wyglądała jego podróż do Rzymu z opatem Wilhelmem, albo jak wyglądały jego rządy opackie w Revesby i Rievaulx; brak wiedzy na temat jego życia publicznego poza klasztorem i jego kontaktów ze światem zewnętrznym, tzn. $z$ wielkimi tego świata; nic nie wiadomo na temat jego podróży do Clairvaux i na zjazdy Kapituły Generalnej do Citeaux lub corocznych wizytacji w czterech filiach klasztoru Rievaulx; nie ma wieści o wielu wizytach Aelreda na dworze królewskim, jego kazaniach wygłaszanych gościnnie za granica, jego misji do skłóconych braci oraz podczas wojny i pokoju, jego wizyt u pustelnika Godrica z Finchale.

Jest tu też kilka nieścisłości chronologicznych. Na przykład w rozdziałach 37-39 Walter zaznacza, że Aelred podjął podróż do Galloway, po śmierci pewnego opata, która miała miejsce w 1166 r., a powrócił 4 lata przed swoją śmiercią, która nastąpiła $\mathrm{w}$ roku $1167^{109}$. Innym zagadnieniem są jego rządy opackie w Revesby, gdzie miał być „miłowany [...] przez cały dwór królewski, a szczególnie przez króla" ${ }^{110}$; Walter pisząc te słowa miał na myśli relacje Aelreda z Henrykiem II, który w tym czasie jeszcze nie był królem.

Krótko mówiąc, Aelred w wydaniu Waltera Daniela to opat schorowany i zniedołężniały, taki, jaki był on w ostatniej dekadzie, a właściwie w ostatnich czterech latach życia. Wtedy był on ciągle w klasztorze, będąc do dyspozycji swych duchowych braci i służąc im radą, mądrością oraz kierownictwem duchowym ${ }^{111}$. Walter pomija szerszą rzeczywistość życia Aelreda, a świętość, jak zdążyliśmy się zorientować, zredukował faktycznie do pokory, modlitwy i miłości, kosztem jego całej bogatej osobowości ${ }^{112}$.

Brakujące elementy życiorysu Aelreda bardzo spłycają i zubażają sylwetkę naszego opata, a przecież był on figurą publiczna, przyjacielem „wielkich” ówczesnego świata, doradcą królów, książąt i szlachty, świetnym i popularnym mówcą i kaznodzieją, historykiem moralnym, humanistą eksperymentującym na dialogach Cycerona, człowiekiem o wielkim rozumie i sercu. Właśnie jako takiego przedstawiają nam go pozostałe źródła historyczno-literackie. Obraz ten zostawili w swoich utworach ówcześni pisarze monastyczni i kronikarze:

${ }^{109}$ Por. Walter Daniel, Vita Aelredi 45-46.

${ }^{110}$ Tamże 29, ed. Powicke, s. F. 68c: „Multum ergo dilectus [...] a toto regno et permaxime a rege".

${ }^{111}$ Por. Dutton, Introduction, s. 80-82.

${ }^{112}$ Por. tamże, 83. 
Ryszard z Hexham ${ }^{113}$, Gilbert z Hoyland ${ }^{114}$, Jocelin z Furness ${ }^{115}$, Reginald $\mathrm{z}$ Durham ${ }^{116}$. Pomocne tu też są dane $\mathrm{z}$ kronik $^{117} \mathrm{i}$ annałów poszczególnych klasztorów i kapituł, wreszcie same utwory Aelreda.

\section{THE BIOGRAPHER OF AELRED OF RIEVAULX AND HIS SORURCES}

\section{(Summary)}

The article was written to illustrate the difficulties we encounter when attempting to convey the biography of Aelred, a famous 12th century English abbot of Rievaulx. The difficulties are linked with the fact that Aelred lived in medieval times and his biography was written in the form of a hagiography. This style of writing was very popular in the middle ages and usually served to emphasize the holiness of a person's life, i.e. to demonstrate an exemplary life of Christian virtues rather than as an attempt to concentrate on biographical details. The latter rather served as points of reference to the person in question and were expressed in hagiographic style, i.e. with focus on models of behavior, achievements and miracles that fit the style, based on examples taken from the Bible and the lives of other popular saints. Written in monastic circles, such works took on the form of biographies of saints and were often written to satisfy a specific cause (T.J. Heffernan). This is the type of biography we are dealing with here. When attempting to convey Aelred's biography in the contemporary meaning of the term, we must first sift through its hagiographic form and supplement information contained therein with other historical and literary sources. In our case, the attempt was carried out in six points, with focus on: the primary source of Aelred of Rievaulx's biography, Vita Aelredi (1); its author, Walter Daniel (2); the reasons why this work was written (3); its hagiographic form (4); the work's internal sources, i.e. sources linked with the author's own circles (5); as well as outside historical and literary sources of information concerning Aelred (6).

Key words: biography and hagiography, Cistercian in British Islands, Aelred of Rievaulx.

${ }^{113}$ Por. Richardus Hagulstadensis, De statu et episcopo Hagulstadensis Ecclesiae, w: The Priory of Hexham: Its Chroniclers, Endowments, and Annals, ed. J. Raine, Publications of the Surtees Society 46/1, Durham 1864, 1-106.

${ }_{114}$ Por. Gillebertus de Hoilandia, Sermones in Canticum Salomonis 41, 6, PL 184, 218.

${ }^{115}$ Por. Jocelinus de Furness, Vita S. Waldeni, ASanc Augusti I 248-257.

${ }^{116}$ Por. Reginaldus Dunelmensis, Libellus de admirandis Beati Cuthberti uirtutibus, ed. J. Raine, Publications of the Surtees Society 1, London 1835, 178-179; tenże, Libellus de vita et miraculis S. Godrici heremitae de Finchale, ed. J. Stevenson, Publications of the Surtees Society 20, London 1847.

${ }^{117}$ Na przykład: Chronicon Angliae Petriburgense (1162), ed. J.A. Giles, New York 1967, $96-$ 98; Cartularium Abbathiae de Rievalle, ed. J.C. Atkinson, Publications of the Surtees Society 83, Durham 1889, 185-188. 
Słowa kluczowe: biografia i hagiografia, cystersi na Wyspach Brytyjskich, Aelred z Rievaulx.

\title{
BIBLIOGRAFIA
}

\author{
Źródła
}

Cartularium Abbathiae de Rievalle, ed. J.C. Atkinson, Publications of the Surtees Society 83, Durham 1889.

Chronicon Angliae Petriburgense, ed. J.A. Giles, New York 1967.

De sancto Alredo abbate et confessore, ed. C. Horstman, w: Nova Legenda Angliae, vol. 1, Oxford 1901, 41-46

Gillebertus de Hollandia, Sermones in Canticum Salomonis, PL 184, 11-252.

Incipit compendium vite sancti Aelredi abbatis rieuallie, ed. C. Horstman, w: Nova Legenda Angliae, vol. 2, Oxford 1901, 544-553.

Jocelinus De Furness, Vita S. Waldeni, ASanc Aug. I 248-257.

Reginaldus Dunelmensis, Libellus de vita et miraculis S. Godrici heremitae de Finchale, ed. J. Stevenson, Publications of the Surtees Society 20, London 1847.

Reginaldus Dunelmensis, Libellus de admirandis Beati Cuthberti uirtutibus, ed. J. Raine, Publications of the Surtees Society 1, London 1835.

Richardus Hagulstadensis, De statu et episcopo Hagulstadensis Ecclesiae, w: The Priory of Hexham: Its Chroniclers, Endowments, and Annals, ed. J. Raine, Publications of the Surtees Society 46/1, Durham 1864, 1-106.

Walter Daniel, Epistula ad Mauricium, ed. i thum. angielskie F.M. Powicke, w: The Life of Ailred of Rievaulx by Walter Daniel, London - New York 1963 (reprint z roku 1950), 65-81.

Walter Daniel, Lamentatio, ed. M.L. Dutton, w: Walter Daniel, The Life of Aelred of Rievaulx \& the Letter to Maurice, tłum. angielskie P. Freeman, Kalamazoo 1994, $140-146$.

Walter Daniel, Vita Ailredi, ed. i thum. angielskie F.M. Powicke, w: The Life of Ailred of Rievaulx by Walter Daniel, London - New York 1963 (reprint z roku 1950), 1-64.

\section{Opracowania}

Bredero A., Bernard of Clairvaux. Between Cult and History, Edinburgh 1996.

Dutton M.L., Introduction to Walter Daniel's 'Vita Aelredi', w: Walter Daniel, The Life of Aelred of Rievaulx \& the Letter to Maurice, Kalamazoo 1994, 1-88.

Groń R., Aelred z Rievaulx - wielki zapomniany średniowiecza, WPT 13 (2005) z. 1, 19-37.

Groń R., Śmierć Aelreda z Rievaulx - między teoria a rzeczywistościa, VoxP 26 (2006) t. $49,195-207$.

Groń R., Śmierć Bernarda z Clairvaux w świetle 'Vita prima', VoxP 28 (2008) t. 52/1, 257-279.

Heffernan T.J., Sacred Biography. Saints and Their Biographers in the Middle Ages, New York - Oxford 1992.

James M.R., Descriptive Catalogue of the Manuscripts in the Library of Jesus College, Cambridge 1895.

LeCLercQ J., Monks and Love in Twelfth-Century France, New York 1987.

McGuire B.P., Friendship and Community. The Monastic Experience 350-1250, Kalamazoo 1988. 
McGuire B.P., Brother and Lover. Aelred of Rievaulx, New York 1994.

Powicke F.M., Ailred of Rievaulx and His Biographer Walter Daniel, „The Bulletin of the John Rylands Library" 6 (1922) nr 3-4, 71-112.

Powicke F.M., Preface, w: Walter Daniel, The Life of Ailred of Rievaulx, ed. and transl. by F.M. Powicke, London - New York 1963 (reprint z roku 1950), s. IX-LXXXIX.

Weinstein D. - Bell R.M., Saints and Society, Chicago 1982. 